\title{
Knowledge, Attitude and Practice of First Aid Among Commercial Drivers: a Case Study of Commercial Drivers at the Central Motor Park, Itam, Uyo, Akwa Ibom State
}

Jasper Eberendu ( $\nabla$ jasfeco@yahoo.com )

UNIVERSITY OF PORT HARCOURT

Research

Keywords: Commercial drivers, First aid, Knowledge, Motor Park, Road traffic accident, Victims

Posted Date: July 1st, 2021

DOl: https://doi.org/10.21203/rs.3.rs-638614/v1

License: (c) (i) This work is licensed under a Creative Commons Attribution 4.0 International License. Read Full License 


\section{Abstract}

One hundred commercial drivers were randomly selected from the Central Motor Park, Itam, Uyo, the capital city of Akwa Ibom State in Nigeria to assess the level of knowledge, attitude and practice of first aid among the commercial drivers in the park. A questionnaire made up of two parts was used. Part $A$ sought the demographic information while Part B sought information on knowledge, attitude and practice of first aid among commercial drivers. Three hypotheses were formulated to guide the study. Data were analyzed using chi-square statistics. The results revealed positive attitudes among the drivers towards the practice of first aid. However, the results also revealed poor knowledge and practice of first aid among the drivers. Recommendations were made for commercial drivers to be involved in first aid training programme organized periodically by the state government and transport companies. Also recommended is the inclusion of first aid training in the driving school curriculum.

\section{Introduction}

First aid is described as a form of treatment given to an ill or injured person by non-medical person(s) in order to prevent degradation of any health threatening situation, which is aimed at saving life and also contributes to the treatment process, before the arrival of a professional medical care practitioner (Joseph, Kumar, Babu, Nelliyanil and Bhaskaran, 2014). It is a treatment for the purpose of preserving life and minimizing the consequences of injury and illness until professional help comes from a trained health care giver or medical practitioner. According to Joseph et al (2014) and Swetha, Suchira \& Sahana (2015), the main purpose of first aid is to relieve pain and prevent the affected individual condition from worsening until the arrival of health care givers.

In Nigeria, reports of road traffic related accidents have continued to pose serious socio-economic problems. Akpoghomeh (2012) explained that a road traffic accident is a mishap, or a chance of events on the road which usually leads to injuries, damages to life and properties or death. Reports have shown that over 1.2 million people are killed in road related crashes around the world annually and as many as 50 million are injured, (Gururaj, 2011; Akpoghomeh, 2012; WHO 2012). A total of $65 \%$ of these incidences usually involve adults while about $35 \%$ often time involved children (WHO, 2004). The World Health Organization, WHO (2012) also estimated that these figures will likely increase by about $65 \%$ by 2050 unless there is new commitment to ensuring decreases in future occurrences and prevention.

It is believed that some of the deaths could be prevented if the drivers have basic first aid knowledge. The Federal Road safety Corps (2011) stated that in Nigeria, there are 35 cars per kilometer of road, indicating inadequate road network which leads to over 4,700 crashes annually (FRSC, 2011). They further stated that there are about 4 casualties (killed and injured) in each crash. With this magnitude of road related incidences, it becomes imperative for driver to know the basic principles and procedures of first aid. Hence, the first aider should be equipped with positive attitude and be prepared to help during casualties. The first aider should also have the adequate knowledge as well as basic skills about what to do, especially by encouraging and reassuring the victims (Deepak \& Nayak, 2012), to avoid panic. 
In most road related accidents, the first responders are usually other drivers. Olugbenga-Bello et al (2012) affirmed that in Nigeria, most times, the first person on the scene of accidents is likely to be another driver; hence they are the ideal population to be singled out for first aid training. Many experts believe that even a limited understanding of first aid would be an invaluable service to individuals who find themselves in emergency situations (Semwal et al. 2013). It is imperative to stress that proper first aid activities administered by non-medical personnel increases the chances of survival of a victim. Therefore, looking on the scale of road accidents and other related injuries, it is necessary to assess the citizens' ability to give first aid, especially motor drivers who are likely the first responders in road traffic accidents. It is against this background that this study will investigate the knowledge, attitude and practice of first aid among commercial drivers at the Central Motor Park, Itam, Uyo, Akwa Ibom State, Nigeria.

\section{Materials And Methods}

The method employed is described as follows:

\section{Description of the Study Area}

The study area is the Central Motor Park, Itam. It is located within Uyo metropolis, the capital city of Akwa Ibom State. It is a major park in the city where commercial drivers operating within and outside state, load and offload goods and passengers. There are over a hundred functioning vehicles comprising of buses, cars, luxuries, trucks and so on. It is one of the busiest parks in Uyo, the capital city of Akwa Ibom State; a state whose major means of transportation is by road.

\section{Research Hypotheses}

1. Drivers are not significantly knowledgeable about first aid.

2. Drivers do not significantly practice first aid.

3. Attitude of drivers towards the practice of first aid is not positive.

\section{Research Design}

This is a descriptive survey research design which aimed at exploring the knowledge, attitude and practice of first aid among commercial drivers at the Central Motor Park, Itam, Uyo, Akwa Ibom State.

\section{Population of the study}

The target population for this study was made up of drivers from the Central Motor Park, Itam, Uyo, Akwa Ibom State of Nigeria.

\section{Sampling Technique}

A random sampling procedure was adopted for the study, with a total of 100 drivers being randomly selected. All the units in the park were grouped into five. The units were Northern route, Eastern route, 
Western route, Southern route and Intra-state route. Twenty drivers were selected from each unit, giving a total of 100 drivers who participated in the study.

\section{Data Collection Instrument}

The instrument used for data collection was a Likert scale questionnaire which consisted of two parts. Part A obtained the demographic information while part B consisted of questions on the knowledge, attitude and practice of first aid among the commercial drivers.

\section{Data Collection Procedure}

The questionnaire was administered personally to the respondents in their respective units to minimize the chances of loss. The drivers were instructed to tick where appropriate and to react freely, independently and honestly. The return rate of the questionnaire was $100 \%$ while the exercise took one day.

\section{Data Analysis Plan}

The data was presented in tables based on each of the hypotheses. The researcher adopted the chisquare $\left(\chi^{2}\right)$ analysis. The hypotheses were all tested at 0.05 level of significance.

\section{Analysis of Data and Discussion}

Table 1: Sex of Drivers

\begin{tabular}{|lll|}
\hline Sex & Frequency & percent \\
\hline Male & 100 & 100 \\
\hline Female & 0 & 0 \\
\hline Total & 100 & 100 \\
\hline
\end{tabular}

Table 1 indicates that $100 \%$ of the respondents were male.

Table 2: Age of drivers

\begin{tabular}{|lll|}
\hline Age (in years) & Frequency & Percent \\
\hline $18-29$ & 15 & 15 \\
\hline $30-49$ & 45 & 45 \\
\hline $50-59$ & 35 & 35 \\
\hline 60 and above & 5 & 5 \\
\hline Total & 100 & 100 \\
\hline
\end{tabular}


Table 2 indicates the age of the drivers, thus; 15 (15\%) were within the age of $18-29$ years. $45(45 \%)$ were within ages $30-49$ years, 35 (35\%) were within the ages of 50-59 years, while $5(5 \%)$ were above 60 years.

Table 3: Educational Qualification of the Drivers

\begin{tabular}{|lll|}
\hline Qualification & Frequency & Percent \\
\hline FSLC & 30 & 30 \\
\hline SSCE & 41 & 41 \\
\hline OND/NCE & 17 & 17 \\
\hline HND/B.Sc/B.A/B.Ed & 12 & 12 \\
\hline Total & 100 & 100 \\
\hline
\end{tabular}

Table 3 indicates that 28 (28\%), 39 (39\%), 12 (12\%) and 6 (6\%) had first school leaving certificate, secondary school examination certificate, Ordinary National diploma/National Certificate in Education and Higher National Diploma/Bachelor's degree respectively.

Table 4: Years of Experience of Drivers

\begin{tabular}{|lll|}
\hline Years of experience & Frequency & Percent \\
\hline $1-5$ years & 10 & 10 \\
\hline $6-10$ years & 15 & 15 \\
\hline $11-15$ years & 39 & 39 \\
\hline 15 years and above & 36 & 36 \\
\hline Total & 100 & 100 \\
\hline
\end{tabular}

Table 4 indicates that 5 (5\%), 15 (15\%), 48 (48\%) and 22 (22\%) of respondents had 1-5 years, 6-10 years, 11-15 years and 15 and above years of experience, respectively.

Table 5: Marital status of the Drivers

\begin{tabular}{|lll|}
\hline Marital status & Frequency & Percent \\
\hline Married & 63 & 63 \\
Single & 12 & 12 \\
\hline Divorced & 19 & 19 \\
Widowed & 6 & 6 \\
\hline Total & 100 & 100 \\
\hline
\end{tabular}

Page 5/10 
Table 5 indicates that $63(63 \%), 12(12 \%), 19(19 \%)$ and $6(6 \%)$ of the respondents were married, single, divorced and widowed respectively.

Hypothesis 1: Drivers Are Not Significantly Knowledgeable about First aid

Table 6 presents the results of chi-square analysis of scores on knowledge of drivers about first aid. A test of hypothesis revealed that the calculated chi-square $\left(\chi^{2}\right)$ value of 2.789 was less than the critical value of 3.84 with 1 degree of freedom at 0.05 level of significance. Hence, the null hypothesis was accepted. Thus, the drivers are not significantly knowledgeable about first aid.

Table 6: Analysis of Respondents on knowledge of First aid

\begin{tabular}{|llllll|}
\hline Statement & $\begin{array}{l}\text { Strongly } \\
\text { agree }\end{array}$ & Agree & $\begin{array}{l}\text { Strongly } \\
\text { disagre }\end{array}$ & Disagree & Total \\
\hline I know the meaning of first aid & 18 & 20 & 25 & 37 & 100 \\
$\begin{array}{l}\text { I know the contents of a first aid box } \\
\text { and their uses }\end{array}$ & 10 & 18 & 42 & 30 & 100 \\
\hline $\begin{array}{l}\text { I have been trained on first aid } \\
\text { I know that first aid can save life }\end{array}$ & 5 & 7 & 48 & 40 & 100 \\
\hline Total & 18 & 25 & 35 & 22 & 100 \\
\hline
\end{tabular}

Hypothesis 2: Drivers Do Not Significantly Practice First Aid

Table 7 presents the results of chi-square analysis of scores on drivers' practice of first aid. A test of hypothesis revealed that the calculated chi-square $\left(\chi^{2}\right)$ value of 3.11 was less than the critical value of 3.84 with 1 degree of freedom at 0.05 level of significance. Hence, the null hypothesis was accepted. Thus, the drivers do not significantly practice first aid.

Table 7: Analysis of Respondents on Drivers' practice of First aid 


\begin{tabular}{|c|c|c|c|c|c|}
\hline Statement & $\begin{array}{l}\text { Strongly } \\
\text { agree }\end{array}$ & Agree & $\begin{array}{l}\text { Strongly } \\
\text { disagree }\end{array}$ & Disagree & Total \\
\hline \multirow[t]{2}{*}{ I always have first aid kits in my vehicle } & 2 & 2 & 41 & 55 & 100 \\
\hline & 14 & 6 & 53 & 27 & 100 \\
\hline \multicolumn{6}{|l|}{ I have helped to save an accident victim } \\
\hline & 5 & 4 & 51 & 40 & 100 \\
\hline \multicolumn{6}{|l|}{ I can administer first aid on a victim } \\
\hline \multirow[b]{2}{*}{$\begin{array}{l}\text { I can use the contents of a first aid kit to } \\
\text { save a victim }\end{array}$} & & 6 & 47 & 44 & 100 \\
\hline & 3 & & & & \\
\hline Total & 24 & 18 & 192 & 166 & 400 \\
\hline
\end{tabular}

Hypothesis 3: Attitude of Drivers Towards the practice of First Aid Is Not Positive

Table 8 presents the results of chi-square analysis of scores on drivers' attitude towards the practice of first aid. A test of hypothesis revealed that the calculated chi-square $\left(\chi^{2}\right)$ value of 9.03 was greater than the critical value of 3.84 with 1 degree of freedom at 0.05 level of significance. Hence, the null hypothesis was rejected. Thus, the attitude of drivers towards the practice of first aid is positive.

Table 8: Analysis of Respondents on Drivers' attitude towards the practice of First aid 


\begin{tabular}{llllll} 
Statement & $\begin{array}{l}\text { Strongly } \\
\text { agree }\end{array}$ & Agree & $\begin{array}{l}\text { Strongly } \\
\text { disagree }\end{array}$ & Disagree & Total \\
\hline I feel every driver should have first aid training & 40 & 32 & 11 & 17 & 100 \\
\hline & 30 & 45 & 14 & 11 & 100
\end{tabular}

I am willing to administer first aid to an

accident victim whenever the

need arises

49

35

9

7

100

I think accident victims should not be left for healthcare personnel alone

$20 \quad 40 \quad 30 \quad 10 \quad 100$

I feel first aid skills and knowledge should be a requirement for driving jobs

Total

139

$152 \quad 64$

45

400

\section{Discussion Of Results}

The study was proposed to determine the knowledge, attitudes and practice of first aid among commercial drivers at the Central motor park, Itam, Uyo, Akwa Ibom State. Three hypotheses were formulated to test the level of knowledge of first aid among the commercial drivers, their attitudes towards first aid and their level of practice of first aid respectively. The results of the analysis revealed that majority of the drivers lacked significant knowledge of first aid. This was exemplified with the lack of knowledge on the meaning of first aid and the contents of a first aid kit noted among the majority. The results also revealed that the drivers did not significantly practice first aid. Almost all of them lacked first aid kits in their vehicle and could not administer first aid. According to the results, the attitude of drivers towards the practice of first aid was positive. This supports a similar work done by Olugbenga-Bello et al (2012) which revealed that majority of the drivers felt first aid was necessary because it would help prevent unnecessary deaths and improve patient outcomes. Majority of them were of the opinion that first aid should not be the business of medical professionals alone, and were also willing to have first aid training.

\section{Summary}

The study was on the knowledge, attitude and practice of first aid among commercial drivers at the Central motor park, Itam, Uyo, Akwa Ibom State. The following were discovered:

- That the majority of the drivers in the park were not knowledgeable about first aid. 
- That the majority of the drivers do not practice first aid.

- That the majority of the drivers were willing to have first aid training and administer first aid on accident victims.

- That the majority of the drivers agreed that first aid should not be left for healthcare personnel alone.

- That first aid knowledge and skill should be a prerequisite for driving jobs.

\section{Recommendations}

Based on the findings, the following recommendations were made:

1. The federal and state governments, through their respective ministries of transportation, transport companies, The Red Cross Society and other stakeholders should synergize and develop a first aid training programme contained in a national first aid manual for all road users.

2. First aid training should be part of the driving school curriculum.

3. The state government and transport companies should organize periodic first aid training for commercial drivers.

4. It should be made mandatory, just like fire extinguishers, to have first aid kits and first aid guide manual in all vehicles.

5. First aid training, first aid kits and a first aid manual should be prerequisite for the issuance of a driver's license.

\section{Conclusion}

Road traffic accidents are usually unexpected and may result in casualties. Quick response to accident victims can reduce the effect of the crash and save life. Commercial drivers, due to their high presence on the roads, are likely to be the first responders to an accident scene, hence, the need for them to have adequate first aid knowledge and skills.

\section{Declarations}

Ethics approval and consent to participate: NOT APPLICABLE

Consent for publication: NOT APPLICABLE

Availability of data and materials: See the references

Competing interests: NOT APPLICABLE

Funding: NOT APPLICABLE

Authors' contributions: See the conclusion and recommendations 
Acknowledgements: I thank the authorities of the Central Motor Park, Itam, Uyo for granting me access to the Park and the permission to interview the commercial drivers in the Park. I appreciate the commercial drivers (my respondents) who gave me the information I needed for this study.

Authors' information: Dr. JASPER I. EBERENDU. HUMAN KINETICS AND HEALTH EDUCATION DEPARTMENT, UNIVERSITY OF PORT HARCOURT, NIGERIA. jasfeco@yahoo.com

\section{References}

Akpoghomeh O. S (2012). The terror of transport and the transportation of terror: An inaugural lecture. Inaugural lecture series, University of Port Harcourt no. 94.

Deepak, M and Nayak, S (2012). A study on assessment of knowledge on practice regarding first aid measures among the self-help groups in selected areas of Mangalore with a view to develop information module. NUJHS 2(3): 68-71.

Federal Road Safety Corps (FRSC) (2011). 2011 Annual Report. Retrieved from www.frsc.gov.ng

Gururaj G. (2011) Road map to road safety in India. Road traffic injury prevention in India. 2011. 83.

Joseph N, Kumar GS, Babu YPR, Nelliyanil M, Bhaskaran U (2014). Knowledge of first aid skills among students of a medical college in Mangalorre City of South India. Ann Med Health Sci Res 4: 162-166

Olugbenga-Bello, A. I, Sunday, O. K, Nicks, B. A, Olawale, O. A and Adefisoye, A. O (2012). First aid knowledge and application among commercial inter-city drivers in Nigeria. African Journal of Emergency Medicine (2012) 2, 108-113

Swetha, C, Suchitra, M. N and Sahana, B. N (2015). "A study on assessment of knowledge, attitude and practices regarding first aid among nursing students." International Journal of Current Research.

Retrieved from www.journalcra.com

Semwal, J, Juyal, R, Singh, M and Candpal, S. D (2013). Rapid assessment of first aid awareness amongst the rural community of Doiwala block, Dehradun. Indian Journal of Community Health, 25 (3): 262-264.

World Health Organization (WHO) (2004). Risk factors: World Report on Road Traffic Injury Prevention. www.who.int

World Health Organization (WHO) (2012). Violence and injury prevention: World report on road traffic injury prevention. www.who.int 